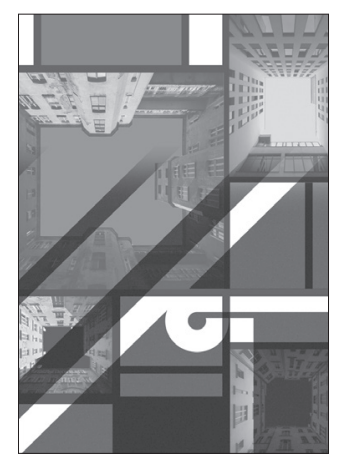

\title{
Krzysztof Mycielski*
}

\author{
Czy idee Bauhausu przystaja do polskiej rzeczywistości XXI w.? \\ Wplyw twórczości Waltera Gropiusa i Ludwika Miesa van der Rohe \\ na współczesne projektowanie na przykladzie realizacji \\ pracowni Grupa 5 Architekci
}

\author{
Do the Bauhaus ideas fit into Polish reality of the $21^{\text {st }}$ century? \\ The influence of the works of Walter Gropius and Mies van der Rohe \\ on contemporary projects on the example of buildings \\ designed by Grupa 5 Architekci
}

\section{Wprowadzenie}

Jaki wpływ ma dziedzictwo Bauhausu na polskie realizacje architektoniczne pierwszych dwóch dekad XXI w.? Zarówno współcześni publicyści, jak i czynni projektowo architekci często pomijają to, iż nie istniało jednoznaczne oblicze Bauhausu. Co oznaczają takie pojęcia jak „bauhausowskie rozwiązanie”, „bauhausowska estetyka” czy „bauhausowskie podejście do projektowania”, które przewijają się w dzisiejszych dyskusjach o projektowaniu? Czy wypowiadane są w pełni świadomie, czy raczej bazują na stereotypie, poprzez który postrzegamy dziś osiągnięcia architektonicznej awangardy?

Bauhaus nie był monolitem. W pierwszych latach okresu weimarskiego mamy Bauhaus ekspresjonistyczny rozwijający się pod wpływem szwajcarskiego malarza mistyka Johannesa Ittena [1]. Po roku 1921, gdy do Weimaru przybył członek grupy De Stijl Theo van Doesburg, szkoła zdominowana została przez neoplastycyzm i konstruktywizm. Inne jest oblicze Bauhausu do roku 1928, gdy dyrektorem szkoły był Walter Gropius - pedagog doceniający

* ORCID: 0000-0001-5334-5131. Wydział Architektury Politechniki Warszawskiej / Faculty of Architecture, Warsaw University of Technology, e-mail: Krzysztof.Mycielski@pw.edu.pl

\section{Introduction}

What is the influence of the Bauhaus heritage on the Polish architectural implementations of the first two decades of the $21^{\text {st }}$ century? Both contemporary journalists and architects who are active in designing often ignore the fact that there was no clear-cut face of Bauhaus. What do the terms "Bauhaus solution", "Bauhaus aesthetics" and "Bauhaus approach to designing" mean that are featured in today's discussions about designing? Are they pronounced consciously or are they based on the stereotype through which we perceive the achievements of the architectural avant-garde today?

Bauhaus was not a monolith. In the first years of the Weimar period, we have an expressionist Bauhaus that developed under the influence of Swiss mystic painter Johannes Itten [1]. After 1921, when a member of the De Stijl group, Theo van Doesburg came to Weimar, the school was dominated by neo-plasticism and constructivism. The face of Bauhaus was different until 1928, when Walter Gropius - an educator who appreciated the diversity of views of the avant-garde of the time and promoted its individual development - was the school's headmaster [2]. The heavily politicized Bauhaus of 1928-1930, based on scientific analyses and rationalist foundations, led by 
różnorodność poglądów ówczesnej awangardy i promujący jej indywidualny rozwój [2]. Inny jest mocno upolityczniony Bauhaus z lat 1928-1930, oparty na naukowych analizach i racjonalistycznych podstawach, kierowany przez Hannesa Meyera. Wreszcie odmienny jest Bauhaus w ostatnich dwóch latach swojego istnienia pod dyrekcją Miesa van der Rohe, gdy staje się przede wszystkim szkołą architektury poszukującą, zgodnie z zainteresowaniami Miesa, formy doskonałej [3].

Dzisiejszym praktykom projektowania różnice te nie wydają się istotne. Po upływie stu lat szkoła Bauhausu postrzegana jest przede wszystkim jako synonim nowoczesności, uosobienie awangardowego myślenia o syntezie sztuk i przede wszystkim - jako pionierska szkoła wzornictwa przemysłowego. Wśród architektów Bauhausu na pierwszy plan wysuwają się dziś dwie najbardziej eksponowane postacie - Walter Gropius i Mies van der Rohe, zaliczani do ścisłej elity modernizmu. Dla obu tych architektów punkt wyjścia stanowiła twórczość niemieckiego modernisty Petera Behrensa, u którego praktykowali w młodym wieku, ale każdy z nich cechował się odmienną osobowością i wniósł odrębny wkład w rozwój architektury współczesnej.

Mies van der Rohe uchodzi w oczach wielu dzisiejszych projektantów za najpełniejszego modernistę. Wypowiedział się perfekcyjnie na prawie każdy temat, wokół którego koncentrowały się poszukiwania funkcjonalistów. Stworzył najwybitniejsze dzieła białego stylu międzynarodowego, doskonały prototyp funkcjonalistycznego domu wielorodzinnego, perfekcyjne budynki - struktury. W najbardziej radykalnej wersji rozwinął współczesną ideę przenikania wnętrza budynku z jego zewnętrzem. Był architektem przez całe życie skrajnie konsekwentnym, ceniącym w architekturze dyscyplinę, porządek, szczerość i ascezę. W publicznych wypowiedziach odwoływał się do myśli św. Augustyna, iż piękno jest blaskiem prawdy (za: [4, s. 12]).

Z kolei Walter Gropius do dziś niezmiennie imponuje otwartością. Był inicjatorem i organizatorem szkoły Bauhausu, twórcą i animatorem zespołu składającego się z wielu wybitnych przedstawicieli różnych dziedzin sztuki, którym pozwalał rozwijać własne pomysły na warsztaty ze studentami. Promował model nauczania oparty na relacji mistrz-uczeń, ale jako dyrektor szkoły, w obliczu podległych mu nauczycieli, potrafił ustawiać się w drugim planie. Doskonale rozumiał opartą na konfrontacji osobowości twórczą pracę zespołową. Stworzył przesycone duchem wspólnoty laboratorium współczesnego rzemiosła i standaryzacji, w którym rozwijano związek sztuki i przemysłu [5]. Nauczanie w Bauhausie w większym stopniu oparł na warsztatowej praktyce niż na teorii. Był jednym z pierwszych architektów podkreślających społeczną rolę swojego zawodu. Postrzegał architekturę jako syntezę wszystkich sztuk. Pod wpływem współpracowników jego zapatrywania stylistyczne ewoluowały wraz z rozwojem tworzonej przez niego szkoły - od fascynacji ekspresjonizmem, czytelnej w manifeście Bauhausu (1919) i w realizacji domu Sommerfelda z 1921 r., do purystycznej czystości form cechujących jego realizacje w Dessau z 1926 r. - zespół szkoły Bauhausu i domy zaprojektowane
Hannes Meyer, is different. Finally, there is yet another Bauhaus in the last two years of its existence under the supervision of Mies van der Rohe, when it becomes primarily a school of architecture seeking, in line with Mies's interests, a perfect form [3].

These differences do not seem significant to today's design practitioners. After one hundred years, the Bauhaus school is seen primarily as a synonym of modernity, the embodiment of avant-garde thinking about the synthesis of arts and, above all, as a pioneering school of industrial design. Among the Bauhaus architects, two most prominent figures come to the fore today - Walter Gropius and Mies van der Rohe, counted among the strict elite of modernism. For both these architects, the starting point was the work of German modernist Peter Behrens, with whom they practiced at a young age, but each of them had a different personality and made a separate contribution to the development of contemporary architecture.

Mies van der Rohe is regarded by many today's designers as the most complete modernist. He spoke perfectly on almost every topic on which the search of functionalists focused. He created the most outstanding works of international white style, a perfect prototype of a functionalist multi-family house, perfect buildings - structures. In the most radical version, he developed the contemporary idea of penetrating the interior of the building including its exterior. He was an extremely consistent architect throughout his life, appreciating discipline, order, honesty and asceticism in architecture. In public statements, he referred to the thoughts of St. Augustine that Beauty is the splendor of Truth $^{1}$ (after: [4, p. 12]).

On the other hand, Walter Gropius continues to impress with openness to this day. He was the initiator and organizer of the Bauhaus school, the creator and animator of a team consisting of many outstanding representatives of various fields of art, whom he allowed to develop his own ideas for workshops with students. He promoted a model of teaching based on the master-student relationship, but as the director of the school he was able to position himself in the background in relation to teachers subordinate to him. He understood perfectly well the creative teamwork based on confrontation of personalities. He created a laboratory of contemporary craftsmanship and standardization, saturated with the spirit of community, in which the relationship between art and industry was developed [5]. His teaching on Bauhaus was based more on workshop practice than on theory. He was one of the first architects to emphasize the social role of his profession. He saw architecture as a synthesis of all arts. Under the influence of his associates, his stylistic views evolved along with the development of the school he created - from a fascination with expressionism, visible in the Bauhaus manifesto (1919) and in the execution of the Sommerfeld's house from 1921, to the purist purity of forms that characterized his projects in Dessau from 1926 - the Bauhaus school team and the houses designed for professors,

1 Blake P., Mies van der Rohe: Architecture and Structure, Penguin Books, Baltimore 1968, p. 15. 
dla profesorów, które stały się jednymi z najważniejszych prototypów nowoczesności.

Celem niniejszego artykułu jest przeanalizowanie tych rozwiązań projektowych i idei obecnych w architekturze Bauhausu, które można dziś zaobserwować w rodzimej praktyce projektowej. Z powodu braku kompleksowych badań nad polską architekturą ostatnich lat zawężono analizę do wybranych dzieł twórców Bauhausu oraz do dorobku jednej współczesnej warszawskiej pracowni - Grupa 5 Architekci, reprezentatywnej dla pokolenia architektów średniego pokolenia, dominującego dziś na polskim rynku. Metoda polega tu na szukaniu analogii, porównywaniu konkretnych rozwiązań oraz ich interpretacji, także w kontekście często różnych założeń i celów przyjętych podczas projektowania.

Idee Bauhausu dotyczące dydaktyki - chociażby takie, jak nauczanie studentów w oparciu o kilkuletnią praktykę i umiejętności rękodzielnicze - są dziś w Polsce prawie nieobecne. Nie istnieje również analogiczna szkoła wyższa, ani nawet pracownia oparta na współpracy przedstawicieli tak wielu dziedzin sztuki. Promowana przez Bauhaus standaryzacja jest dziś w polskiej architekturze ideą wciąż przebrzmiałą, zaś społeczna rola architekta przeważnie nie wytrzymuje konfrontacji z rynkową rzeczywistością. We współczesnych polskich budynkach czytelne są natomiast liczne konkretne rozwiązania stosowane przez twórców związanych z Bauhausem. Stały się kanonem dla architektury współczesnej, np. kompozycja zrównoważona, wolna elewacja, przestrzenny rozdział funkcji, podkreślanie konstrukcyjnej struktury budynku czy charakterystyczny dla architektów Bauhausu detal architektoniczny.

\section{Architekci polskiej transformacji}

Pracownia Grupa 5 Architekci powstała w 1998 r., została założona przez pięciu warszawskich architektów młodego pokolenia. Skład osób kierujących pracownią zmieniał się w ciągu ostatnich dwóch dekad. Spośród siedmiu architektów, którzy współprowadzą dziś pracownię, czterej - Roman Dziedziejko, Michał Leszczyński, Krzysztof Mycielski i Rafał Zelent - to projektanci, którzy studiowali na Wydziale Architektury Politechniki Warszawskiej na przełomie lat 80. i 90. XX w. [6, s. 163, 164]. W tym okresie znaczących przewartościowań w architekturze polskiej dyskurs architektoniczny charakteryzujący się mnogością idei - od dogmatycznego modernizmu, przez postmodernizm, dekonstruktywizm i neomodernizm - miał wpływ na kształtowanie się wśród młodych architektów pluralistycznego podejścia do projektowania [7]. Projektanci z Grupy 5, zwłaszcza w pierwszych latach samodzielnej działalności, musieli zmierzyć się z realiami polskiej transformacji, co oznaczało konieczność żmudnego dostosowywania się do chwiejnego rynku usług projektowych i przełożyło się na elastyczną i otwartą formułę współpracy z zagranicznymi biurami architektonicznymi [6, s. 52-56]. Wśród europejskich pracowni, z którymi Grupa 5 Architekci współpracowała po roku 1998, były m.in.: Foster \& Partners z Londynu, Erick van Egeeraat Associated Architects $\mathrm{z}$ Rotterdamu, ALA Architects which have become one of the most important prototypes of modernity.

The purpose of this article is to analyze those design solutions and ideas present in Bauhaus architecture that can be observed today in the domestic design practice. Due to the lack of comprehensive research on Polish architecture of recent years, the analysis has been narrowed down to selected works of Bauhaus creators and to the achievements of one contemporary Warsaw studio - Grupa 5 Architekci, representative for the middle age generation of architects that dominates the Polish market today. The method here consists in looking for analogies, comparing specific solutions and their interpretation, also in the context of frequently different assumptions and goals adopted during designing.

Bauhaus ideas regarding teaching - such as teaching students based on several years of practice and handicraft skills - are almost absent in Poland today. There is no analogous university, nor even a studio based on the cooperation between representatives of so many fields of art. The standardization promoted by Bauhaus today is still an out-of-date idea in Polish architecture, and the social role of an architect usually does not stand up to the market reality. In contemporary Polish buildings, on the other hand, there are visible many specific solutions used by artists associated with Bauhaus. They have become a canon for contemporary architecture, e.g. a balanced composition, a free façade, spatial separation of functions, emphasizing the construction structure of a building or architectural detail characteristic for Bauhaus architects.

\section{Architects of the Polish transformation}

Grupa 5 Architekci studio was established in 1998 by five young generation Warsaw architects. The composition of the studio's managers has changed over the past two decades. Out of the seven architects who co-run the studio today, four of them: Roman Dziedziejko, Michal Leszczyński, Krzysztof Mycielski and Rafał Zelent - are designers who studied at the Faculty of Architecture of the Warsaw University of Technology at the turn of the 1990s [6, pp. 163, 164]. During this period of significant revaluation in Polish architecture, the architectural discourse characterized by a multitude of ideas - from dogmatic modernism, through postmodernism, deconstructivism and neo-modernism - influenced the formation of a pluralistic approach to design among young architects [7]. Designers from Grupa 5, especially in the first years of independent activity, had to face the realities of the Polish transformation, which meant the necessity of tedious adaptation to the realities of the volatile market of design services and resulted in a flexible and open formula of cooperation with foreign architectural offices [6, pp. 5256]. Among the European studios with which Grupa 5 Architekci cooperated after 1998, there were: Foster \& Partners from London, Erick van Egeeraat Associated Architects from Rotterdam, ALA Architects from Helsinki, BAAS Arquitectura from Barcelona and ATP Thomas Pucher from Graz. In 2018, the Warsaw studio employed 52 architects [6, pp. 169-171]. 

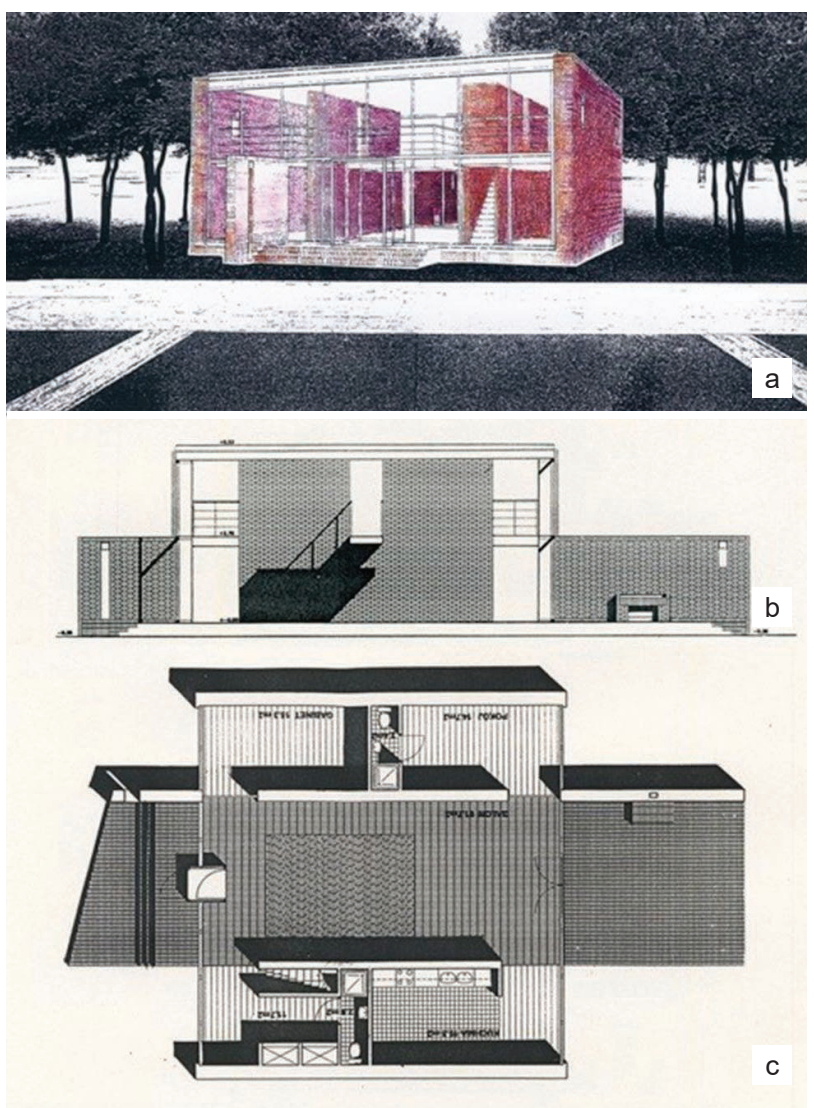

Il. 1. Projekt konkursowy na dom z cegły (1997): a) wizualizacja, b) przekrój podłużny, c) rzut przyziemia (autorzy: R. Dziedziejko, P. Kudelski, M. Łańcucki, K. Mycielski)

Fig. 1. A competition design for a brick house (1997): a) visualization, b) longitudinal section, c) floor plan (authors: R. Dziedziejko, P. Kudelski, M. Łańcucki, K. Mycielski)

z Helsinek, BAAS Arquitectura z Barcelony czy ATP Thomas Pucher z Grazu. W roku 2018 warszawska pracownia zatrudniała 52 architektów [6, s. 169-171].

Estetyka i metoda kształtowania przestrzeni obecna w awangardowej architekturze okresu międzywojennego jest ważnym, choć nie jedynym, źródłem inspiracji czytelnym w realizacjach Grupy 5 Architekci. Stałą fascynację w pracowni stanowi od lat ascetyczna i minimalistyczna estetyka Miesa van der Rohe. Jej wpływ na architektów z Grupy 5 dobrze czytelny był już w projekcie konkursowym na dom z cegły z 1997 r., którego współautorami są Roman Dziedziejko i Krzysztof Mycielski [6, s. 22, 23] (il. 1). Ceglane ściany wybiegające $z$ wnętrza budynku na zewnątrz służą zacieraniu granic obiektu, podobnie jak w projekcie ceglanej willi narysowanym przez Miesa w 1923 r. W transparentnym domu wyeksponowano jego konstrukcję, inspirując się również domem Edith Farsworth w Plano z lat 1946-1951. Puryzm Miesa van der Rohe i jego fascynacja budynkiem jako przestrzenną strukturą, podkreślającą konstrukcyjną logikę obiektu, które wróciły powszechnie do projektowania wraz z neomodernizmem, są dziś wyraźnie czytelne w projektach wielu współczesnych polskich pracowni, takich jak m.in.: JEMS Architekci, HS99, Maćków Pracownia Projektowa, KWK Promes czy BGGK Architekci.
The aesthetics and method of shaping the space present in the avant-garde architecture of the interwar period is an important, although not the only one, source of inspiration visible in the projects implemented by Grupa 5 Architekci. The ascetic and minimalist aesthetics of Mies van der Rohe has been a continuous fascination in the studio for many years. Its influence on the architects from Grupa 5 was well visible already in the competition project of a brick house from 1997, co-authored by Roman Dziedziejko and Krzysztof Mycielski [6, pp. 22, 23] (Fig. 1). The brick walls protruding from the inside of the building to the outside serve to blur the boundaries of the building, similarly like in the design of a brick villa drawn by Mies in 1923. The transparent house exhibits its construction, inspired by Edith Farsworth's house in Plano from 1946-1951. Mies van der Rohe's purism and his fascination with the building as a spatial structure, emphasizing the structural logic of the object, which have come back to design with neo-modernism, are now clearly visible in the designs of many contemporary Polish design offices, such as: JEMS Architekci, HS99, Maćków Pracownia Projektowa, KWK Promes and BGGK Architekci.

The influence of the achievements of the modernist avant-garde on the projects of Grupa 5 Architekci has never been of a doctrinal nature. The architects who founded the studio encountered criticism of the ideological assumptions of functionalism already during their studies $[6$, pp. 14, 15]. The area of their most important interests today (as in the case of many contemporary Polish studios) is the idea of sustainable development, designing of public space based on the observation of people's feelings and behaviors in the city, protection of historical heritage or the search for identity in architecture [6]. In the days of Bauhaus facing the challenges of mass production, these issues were either largely absent or of secondary importance.

\section{A balanced composition - the house in Morskie Oko Street in Warsaw}

A single-family building at 1 Morskie Oko Street in Warsaw's Mokotów district was designed in the Grupa 5 Architekci studio in 2012-2013. The house is crowned with the slope of the Warsaw escarpment rising above the Morskie Oko Park. It is the last and the most exposed building closing an intimate row of contemporary city villas along the street, erected as part of the same investment and designed by three different design studios ${ }^{2}$ [8].

The authors from Grupa 5 Architekci, due to the historic vicinity of the building designed by them, which consists of several modernist tenement houses from the interwar period, located on the escarpment, from the very beginning searched for a purist façade composition based on the principle of the opposition of full bright walls and window openings emphasized by graphic dark woodwork. Thanks to the use of large-format windows and skylights, the sun

2 The urban concept of the entire complex was designed by the LPA studio and arch. Marcin Rubik. 
Wpływ dorobku modernistycznej awangardy na realizacje Grupy 5 Architekci nigdy nie miał jednak doktrynalnego charakteru. Architekci, którzy założyli pracownię, zetknęli się już w czasie studiów z krytyką ideowych założeń funkcjonalizmu [6, s. 14, 15]. Obszarem ich najważniejszych dzisiejszych zainteresowań (podobnie jak w przypadku wielu współczesnych polskich pracowni) jest idea zrównoważonego rozwoju, projektowanie przestrzeni publicznej w oparciu o obserwację odczuć ludzi i ich zachowań w mieście, ochrona historycznego dziedzictwa czy poszukiwanie tożsamości w architekturze [6]. W czasach Bauhausu mierzącego się z wyzwaniami masowej produkcji, zagadnienia te były bądź w większości w ogóle nieobecne, bądź drugorzędne.

\section{Kompozycja zrównoważona - dom przy ul. Morskie Oko w Warszawie}

Budynek jednorodzinny przy ul. Morskie Oko 1 na warszawskim Mokotowie zaprojektowany został w pracowni Grupa 5 Architekci w latach 2012-2013. Dom wieńczy zbocze warszawskiej skarpy wznoszącej się ponad Parkiem Morskie Oko. Obiekt stanowi ostatni i zarazem najbardziej wyeksponowany budynek zamykający kameralny ciąg współczesnych willi miejskich wzdłuż ulicy, wzniesionych w ramach tej samej inwestycji i zaprojektowanych przez trzy różne pracownie projektowe ${ }^{1}$ [8].

Autorzy z Grupy 5 Architekci, ze względu na historyczne sąsiedztwo projektowanego przez nich budynku, które składa się z kilku zlokalizowanych na skarpie modernistycznych kamienic z okresu międzywojennego, od początku poszukiwali purystycznej kompozycji elewacji opartej na zasadzie przeciwieństwa pełnej jasnej ściany i otworów okiennych podkreślonych graficzną ciemną stolarką. Dzięki zastosowaniu wielkoformatowych okien i świetlików słońce przenika do budynku ze wszystkich stron, zaś tłem dla wnętrza stają się korony otaczających drzew. Obszerne tarasy wieńczące obiekt zapewniają atrakcyjny kontakt z otaczającą zielenią, rekompensując niewielką powierzchnię ogrodu. Projektanci wykorzystali tu modernistyczną zasadę łączenia przestrzeni zewnętrznej $\mathrm{z}$ wewnętrzną. Asymetrycznie formowana bryła podkreślona horyzontalnymi otworami okiennymi i tarasami na dachu tworzy interesującą kubistyczną kompozycję.

Zarówno w ascetycznej estetyce budynku, jak i w sposobie kształtowania jego elewacji widać wyraźną analogię do rozwiązań zastosowanych przez Gropiusa przy projektowaniu domów profesorów w Dessau (1925-1926). Budynki te zaliczane są dziś do funkcjonalistycznych prototypów, w których zawarty jest postulat zastąpienia symetrycznych brył kompozycją form zrównoważonych. Tarasy do kąpieli słonecznych, wielkoformatowe okna (zarówno klatek schodowych, jak i pomieszczeń pracowni) otwierają te budynki na otaczającą zieleń. Rozwiązania te miały charakter manifestu artystycznego, chociaż były dyskusyjne od strony praktycznej, chociażby ze

\footnotetext{
1 Koncepcję urbanistyczną całego zespołu zaprojektowała pracownia LPA oraz arch. Marcin Rubik.
}

penetrates the building from all sides, while the crowns of the surrounding trees become the background for the interior. The spacious terraces topped on the building provide an attractive contact with the surrounding greenery, compensating for the small area of the garden. Designers used the modernist principle of combining the external and the internal spaces. An asymmetrically shaped body highlighted by horizontal window openings and roof terraces creates an interesting cubist composition.

Both the ascetic aesthetics of the building and the method of shaping its façade show a clear analogy to the solutions used by Gropius when designing the houses of professors in Dessau (1925-1926). These buildings are today considered to be functionalist prototypes, which include the postulate of replacing symmetrical shapes with a composition of balanced forms. Terraces for sunbathing, large-format windows (both in staircases and in studio rooms) open these buildings to the surrounding greenery. These solutions had the character of an artistic manifesto, although they were debatable from the practical point of view, if only because of the costs of heating [9, p. 126]. In the project implemented by Grupa 5 Architekci, the references to these solutions are not, however, literal. In the objects by Gropius, the aesthetic references to the motifs used by the Dutch group De Stijl are clearer than in the Warsaw building - for example expressed in the Mondrian colors of the interiors. But the most important differences are visible in the finish standard. The Warsaw house is an exclusive building, finished outside with expensive limestone and basalt slabs. Contrary to the buildings in Dessau, it is devoid of balconies that could suggest a lower status of the facility, giving it the character of a standard residential building. The houses of professors in Dessau, although comfortable at the time, do not dazzle with splendor, fitting into the formula of searching for economic solutions, which were the essence of the interests of the founders of the Bauhaus school (Figs. 2, 3).

\section{Free façade - office building in Piękna Street in Warsaw}

The modernist postulate of using a free façade, thanks to the use of the possibilities offered by the reinforced concrete framework, was manifested by Gropius with a glass curtain wall in the building of the workshop of the Bauhaus school in Dessau, established in 1925-1926. The idea was preceded by Gropius' construction of the Fagus factory in Alfeld in 1911, which featured the first pillarless glazed corner in contemporary architecture. According to Nikolaus Pevsner: There is something sublime in this effortless mastery of material and weight. Never since the Sainte-Chapelle and the choir od Beauvais had the human art of building been so triumphant over matter ${ }^{3}$ [5, p. 215].

Architects from Grupa 5 used the idea of Gropius when designing an office building at 49 Piękna Street, in

\footnotetext{
3 Pevsner N., Pioneers of Modern Design. From William Morris to Walter Gropius, Penguin Books, Middlesex-Auckland 1977, p. 216.
} 
względu na koszty ogrzewania [9, s. 126]. W realizacji Grupy 5 Architekci odniesienia do tych rozwiązań nie sa jednak dosłowne. W obiektach autorstwa Gropiusa bardziej czytelne niż w warszawskim budynku są estetyczne nawiązania do motywów stosowanych przez holenderską grupę De Stijl - chociażby wyrażone w pojawiających się we wnętrzach mondrianowskich ko- the southern part of the Center of Warsaw in the years 2010-2015. The building serves as a seal in the urban tissue that has survived the war and fills the sharp corner at the corner of Piękna and Koszykowa streets. The building, as suggested by the Warsaw Conservator of Monuments, is entirely glazed, light with an arcade on the ground floor so that it does not dominate the historical surroundings.
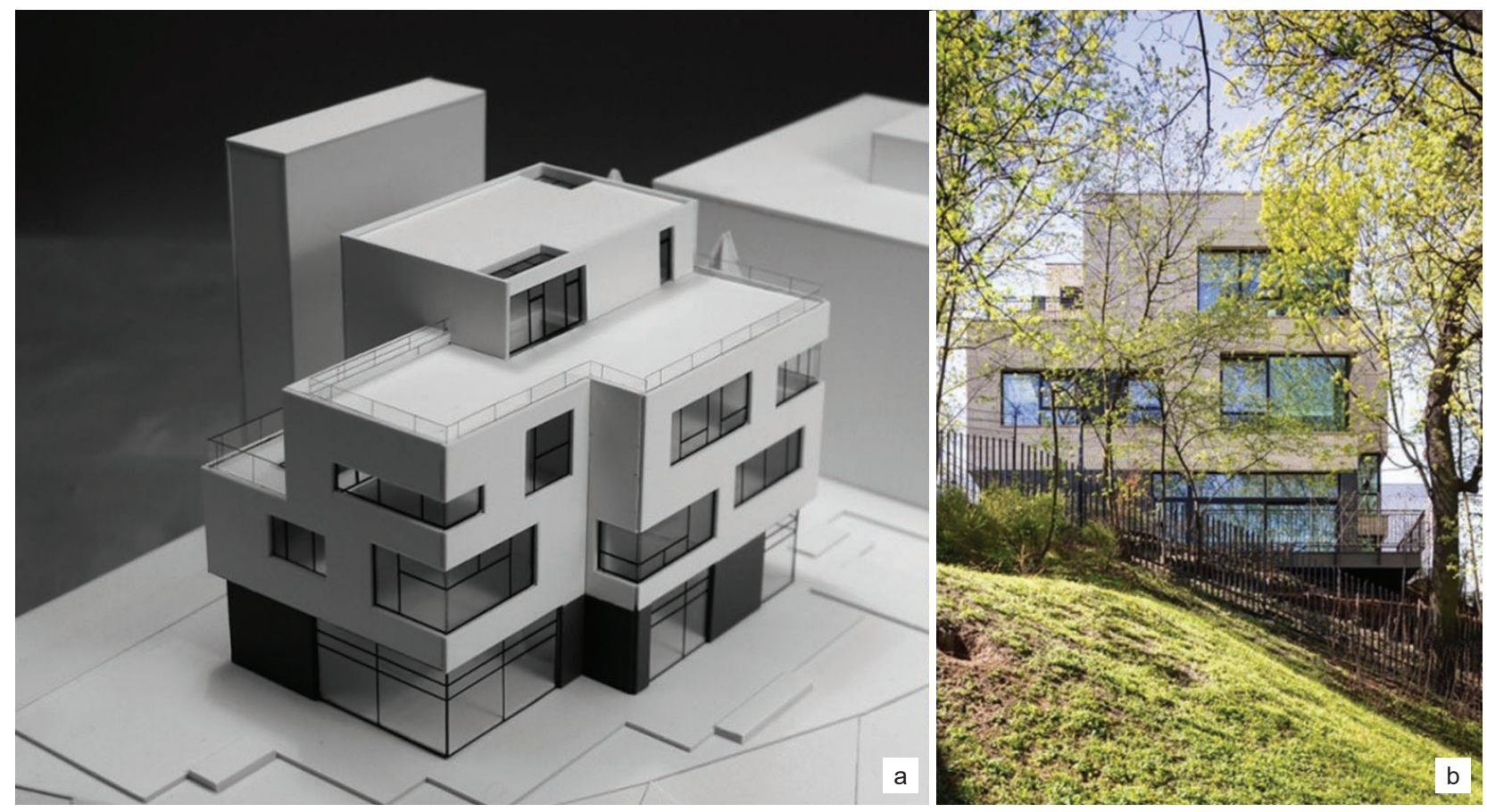

Il. 2. Dom na skarpie przy ul. Morskie Oko w Warszawie (2015) autorstwa Grupa 5 Architekci: a) makieta, b) budynek (zdjęcie makiety: archiwum Grupa 5 Architekci; zdjęcie budynku: M. Czechowicz)

Fig. 2. House on the escarpment in Morskie Oko Street in Warsaw (2015) by Grupa 5 Architekci: a) model, b) building (photo of the model: the archive of Grupa 5 Architekci; photo of the building: M. Czechowicz)
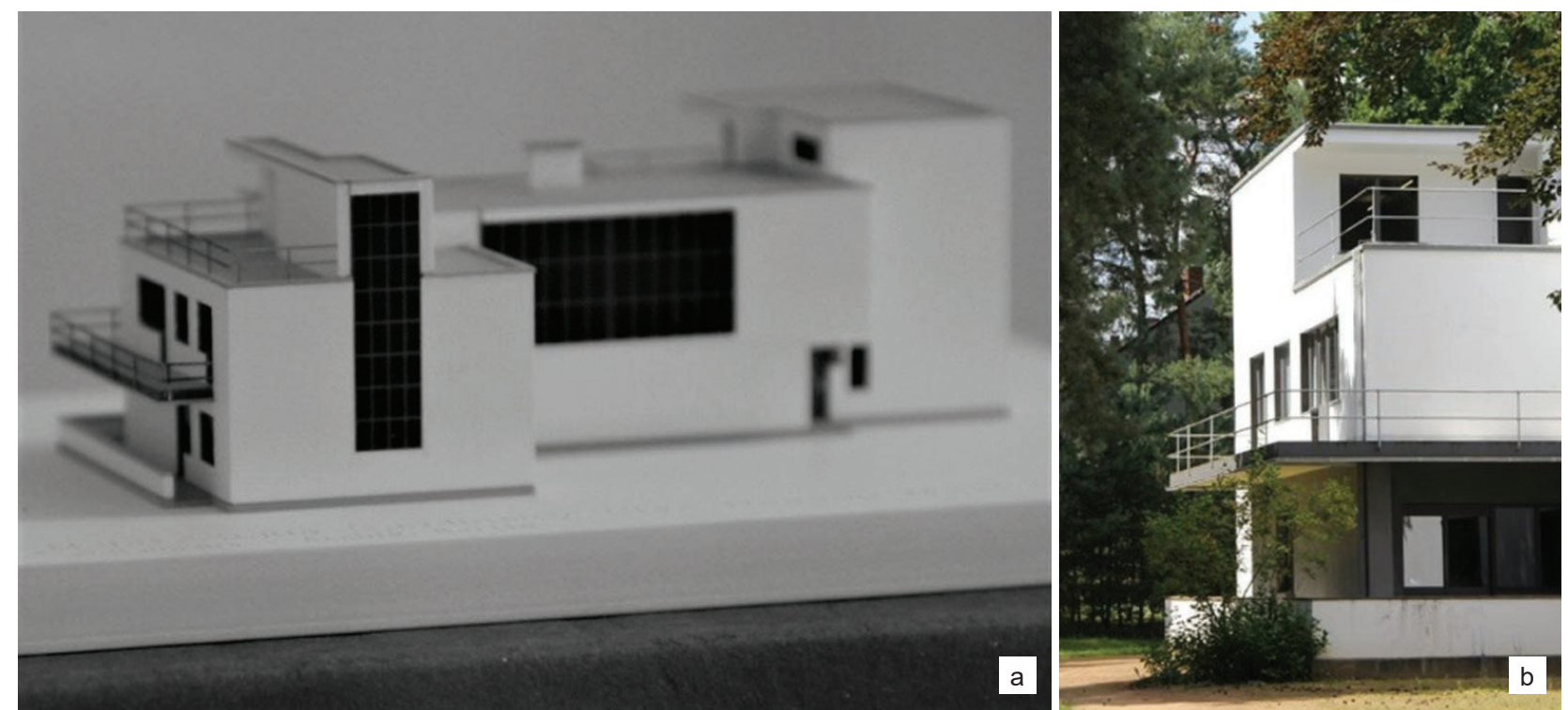

Il. 3. Zlokalizowany w sosnowym lesie w Dessau bliźniaczy dom profesorów Bauhausu (1925-1926), w którym mieszkali Wassily Kandinsky i Paul Klee: a) makieta prezentowana w muzeum w Dessau, b) fragment budynku (fot. K. Mycielski)

Fig. 3. The twin house of the Bauhaus professors located in a pine forest in Dessau (1925-1926), where Wassily Kandinsky and Paul Klee lived: a) a model presented in the museum in Dessau, b) a fragment of the building (photo by K. Mycielski) 
lorach. Ale najważniejsze różnice widoczne są w standardzie wykończenia. Warszawski dom jest budynkiem ekskluzywnym, wykończonym na zewnątrz drogimi płytami z wapienia i bazaltu. W przeciwieństwie do budynków z Dessau pozbawiony jest balkonów, które mogłyby sugerować niższy status obiektu, nadając mu charakter standardowego budynku mieszkalnego. Domy profesorów w Dessau, choć na ówczesne czasy komfortowe, nie epatują przepychem, mieszcząc się w formule poszukiwań rozwiązań ekonomicznych, które stanowiły istotę zainteresowań twórców szkoły Bauhausu (il. 2, 3).

\section{Wolna elewacja - biurowiec przy ul. Pięknej w Warszawie}

Modernistyczny postulat stosowania wolnej elewacji, dzięki wykorzystaniu możliwości, które daje żelbetowy szkielet konstrukcyjny, zamanifestowana została przez Gropiusa przeszkloną ścianą osłonową w budynku warsztatów szkoły Bauhausu w Dessau powstałej w latach 1925-1926. Idea poprzedzona została przez Gropiusa realizacją fabryki Fagus w Alfeld w roku 1911, w której pojawiło się pierwsze w architekturze współczesnej bezfilarowe przeszklone naroże. Zdaniem Nikolausa Pevsnera: Jest coś wzniosłego $w$ tym nie znajacym wysitku mistrzostwie panowania nad tworzywem i ciężarem. Nigdy dotą - od czasów Sainte Chapelle i prezbiterium (katedry) w Beauvais - wynaleziona przez człowieka sztuka budowania nie odniosła podobnego triumfu nad materia [5, s. 215].

Architekci z Grupy 5 wykorzystali ideę Gropiusa, projektując w latach 2010-2015 budynek biurowy przy ul. Pięknej 49 w południowym śródmieściu Warszawy. Obiekt stanowi plombę $\mathrm{w}$ ocalałej $\mathrm{z}$ wojny czynszowej tkance miejskiej i wypełnia ostrokątny narożnik u zbiegu ul. Pięknej i Koszykowej. Budynek, zgodnie z sugestią Stołecznego Konserwatora Zabytków, jest w całości przeszklony, lekki z podcieniem w obrębie parteru, aby nie zdominował historycznego otoczenia. Nadwieszoną nad chodnikiem wąską i delikatnie ekspresyjną bryłę budynku podzielono na trzy segmenty, które tworzą półtransparentny korpus z widocznymi wnętrzami. W szklanych elewacjach odbijają się detale eklektycznych kamienic i zlokalizowanej po drugiej stronie ulicy zabytkowej Hali Koszyki. Zarówno za pomocą kontrastu, jak i dzięki transparentności i refleksom widocznym na fasadzie budynek wydobywa walory eklektycznego otoczenia, podkreślając pierwotny układ urbanistyczny tego rejonu Warszawy [10] (il. 4).

Szklana ściana osłonowa szkoły Bauhausu w Dessau to modernistyczny postulat skrajnego zacierania granic wnętrza budynku (il. 5). Halę warsztatów maksymalnie wypełniało światło naturalne, zaś akademickie życie wewnątrz obiektu miało być widoczne z ulicy. Analogiczne rozwiązanie zastosowane $\mathrm{w}$ warszawskim biurowcu nie stanowi już dziś manifestu nowoczesności ani też nie ma kreować w przestrzeni miasta teatru z udziałem użytkowników. Szklana ściana osłonowa, w dzisiejszych czasach będąca standardowym rozwiązaniem technicznym, jest tu świadomie wybranym tworzywem spośród wielu współczesnych materiałów, za pomocą których architekci mogli ukształtować formę zewnętrzną. W tym wypadku pozwo-
The narrow and delicately expressive body of the building, hanging over the sidewalk, is divided into three segments that create a semi-transparent body with visible interiors. The glass façades reflect the details of eclectic tenement houses and the historic Hala Koszyki located on the other side of the street. By means of contrast and thanks to the transparency and reflections visible on the façade, the building brings out the values of the eclectic surroundings, emphasizing the original urban layout of this part of Warsaw [10] (Fig. 4).

The glass curtain wall of the Bauhaus school in Dessau is a modernist postulate of extreme blurring of the boundaries of the building's interior (Fig. 5). The workshop hall was filled to the maximum with natural light, and the academic life inside the building was to be visible from the street. The analogous solution applied in the Warsaw office building is no longer a manifesto of modernity, nor is it intended to create a theater within the city space with the participation of users. The glass curtain wall, which is nowadays a standard technical solution, is a consciously chosen material from among many contemporary materials with which architects could shape the external form. In this case, it allowed them for an optimal solution referring to the demanding context.

\section{Spatial distribution of functions - primary school in Podkowa Leśna}

The functionalist layout of the Bauhaus school building in Dessau with the division of the body into legibly articulated parts, each of which is a separate functional block, is reflected in the plan of the St. Therese of the Child Jesus Primary School, designed in stages by Grupa 5 Architekci in the years 2006-2015 in Podkowa Leśna.

Gropius particularly liked to present the solution of the Bauhaus school on aerial photos, which showed clearly the differences between its individual parts - the workshop building with a glass façade, the dormitory with a canteen, the wing of the arts and crafts school (Fig. 6). In his opinion, you have to walk right round the whole building in order to appreciate its corporeality and the function of its members $[9$, p. 121]. Similarly, all three parts of the building designed by Warsaw architects in Podkowa Leśna - a group of primary school classrooms located in the center of the building, a block constituting a junior high school (today part of the primary school for older classes) and a gymnasium with back-up facilities - have their own separate body with a separate entrance, so they are able to function independently (Fig. 7). Similarly to the Bauhaus building in Dessau - the functions of the building separated in the space are connected by connecting passageways, and the management and administration rooms are located in the center of the entire system.

However, in terms of interpretation, the similarity of the two solutions is not obvious. Gropius, fragmenting the body of the school in Dessau, referred to the postulates of Theo van Doesburg who was striving to break the axial systems and the hierarchy of façades occurring in traditional architecture. This approach has become one of the basic postulates of the avant-garde in opposition 


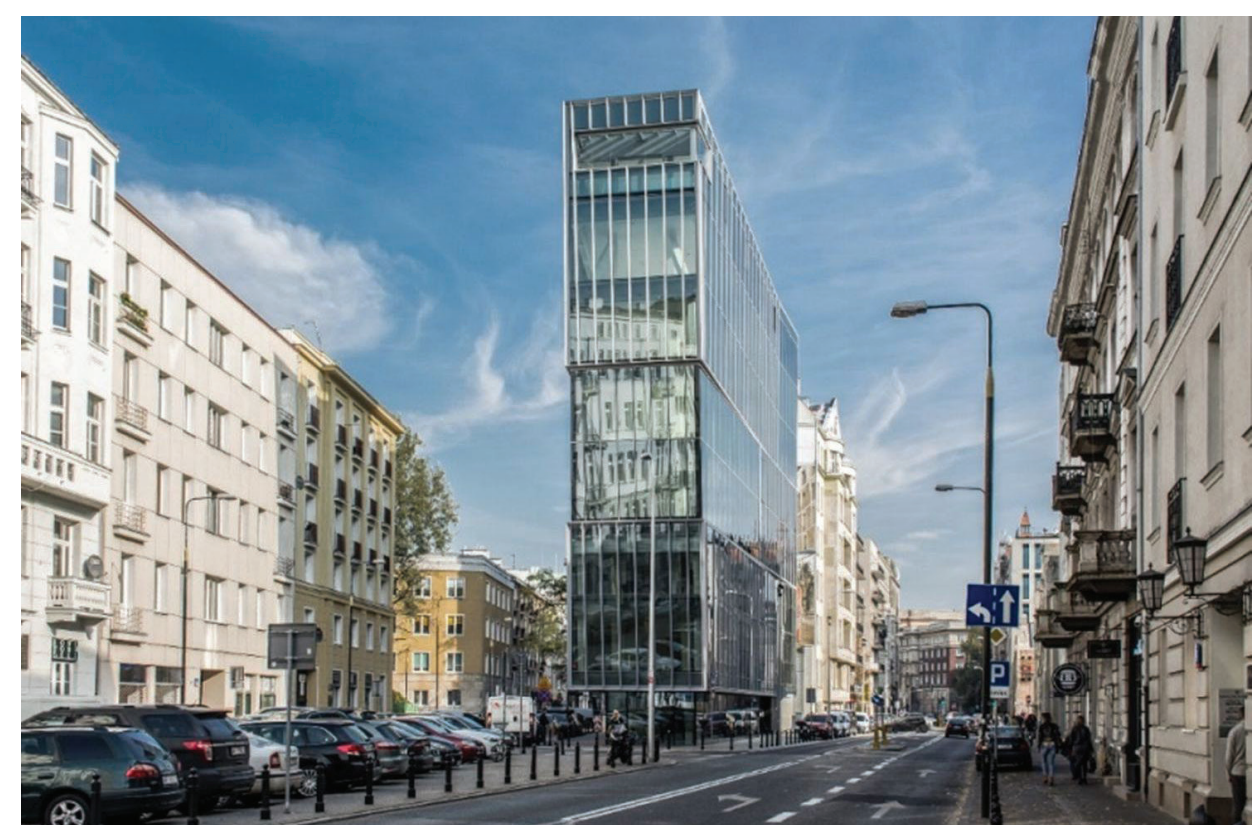

Il. 4. Biurowiec The Nest przy ul. Pięknej w Warszawie (2017) autorstwa Grupa 5 Architekci (fot. M. Lelewski)

Fig. 4. The Nest office building in Piękna Street in Warsaw (2017) designed by Grupa 5 Architekci (photo by M. Lelewski)

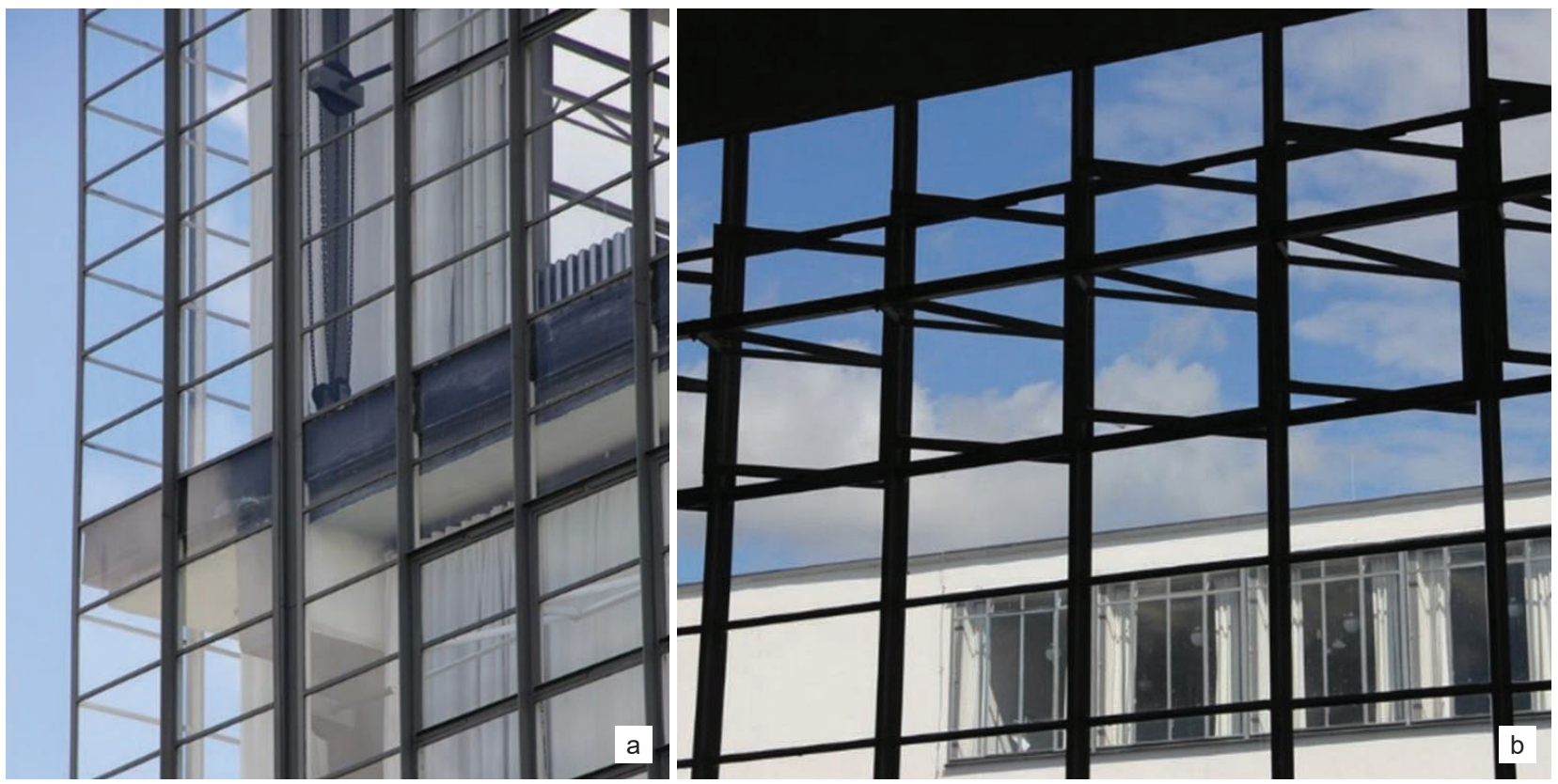

Il. 5. Fragmenty wykonanej przez rzemieślników ściany osłonowej budynku warsztatów szkoły Bauhausu w Dessau (fot. K. Mycielski)

Fig. 5. Fragments of the curtain wall of the workshop building of the Bauhaus school in Dessau made by craftsmen (photo by K. Mycielski)

liło im to na optymalne rozwiązanie nawiązujące do wymagającego kontekstu.

\section{Przestrzenny rozdzial funkcji - szkota podstawowa w Podkowie Leśnej}

Do funkcjonalistycznego rozplanowania budynku szkoły Bauhausu w Dessau z podziałem bryły na czytelnie wyartykułowane części, z których każda stanowi osobny blok funkcjonalny, nawiązuje plan Szkoły Podstawowej im. św. Teresy od Dzieciątka Jezus zaprojektowanej etapami przez Grupę 5 Architekci w latach 2006-2015 w Podkowie Leśnej. to the strictly hierarchical architecture of the $19^{\text {th }}$ century. The school in Dessau has no fronton - at least four façades of the building are almost equivalent, and all others are equally accessible for the user.

In turn, in the school in Podkowa Leśna, the fragmentation of the body of the building is mainly dictated by the optical reduction of its scale, so that it does not dominate the garden that stretches around the city with the intimate church adjacent to the school, and single-family houses standing among the trees. Clearly presentable and more materially invested façades with entrances to all three sections of the school building are located on the side of the streets. At the same time, the largest cubature of the 


\section{Il. 6. Makieta gmachu szkoły Bauhausu w Dessau prezentowana w Muzeum} Bauhausu (fot. K. Mycielski)

Fig. 6. A model of the Bauhaus school building in Dessau presented at the Bauhaus Museum (photo by K. Mycielski)

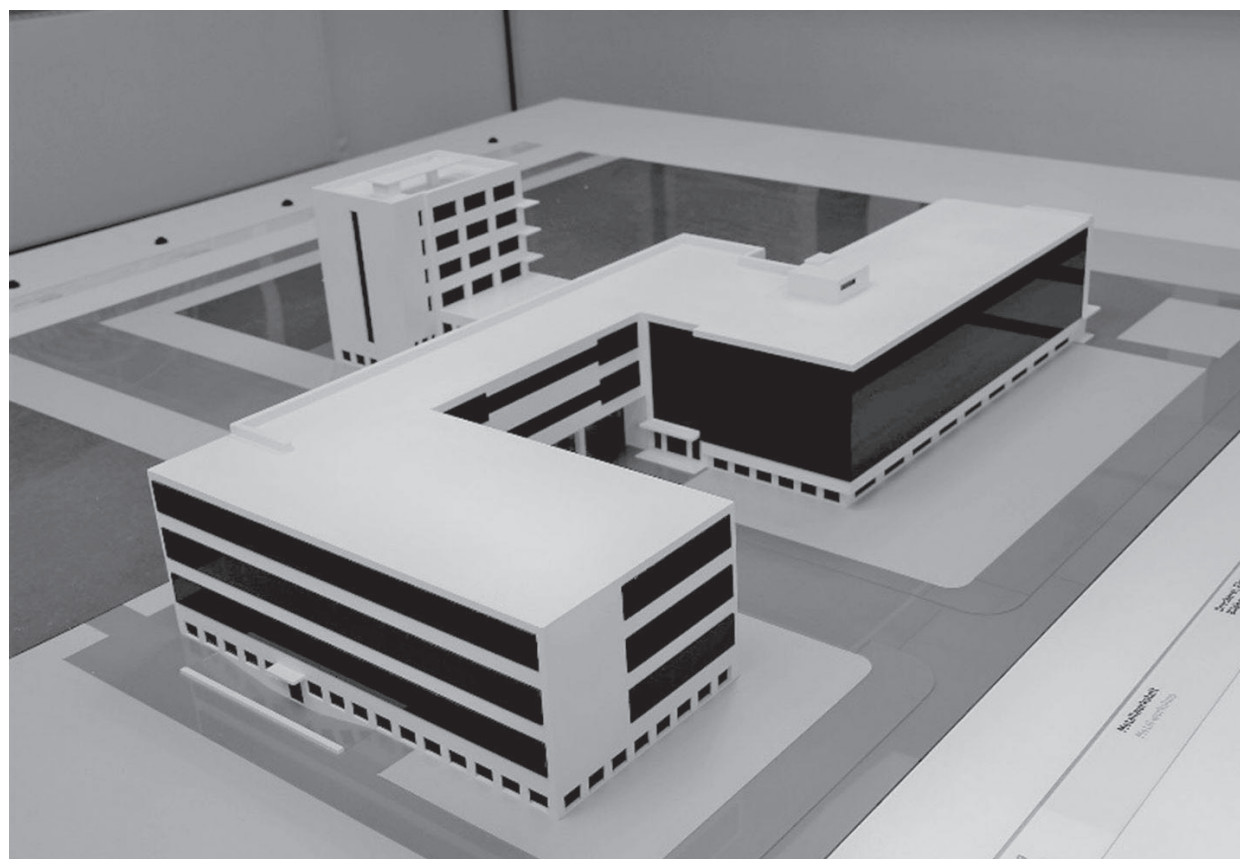

Gropius szczególnie lubił prezentować rozwiązanie szkoły Bauhausu na zdjęciach lotniczych, na których czytelne były różnice pomiędzy jego poszczególnymi częściami - budynkiem warsztatów z przeszkloną fasadą, domem akademickim ze stołówką, skrzydłem szkoły artystycznej i rzemiosła (il. 6). Jego zdaniem: Trzeba obejść cały budynek, aby docenić jego cielesność i funkcje jego poszczególnych członków [9, s. 121]. Podobnie wszystkie trzy części, z których składa się obiekt zaprojektowany przez warszawskich architektów w Podkowie Leśnej - zlokalizowany w centrum budynku zespół sal lekcyjnych szkoły podstawowej, blok stanowiący gimnazjum (dziś część szkoły podstawowej dla starszych klas) oraz sala gimnastyczna z zapleczem - mają własną osobną bryłę $\mathrm{z}$ oddzielnym wejściem, dzięki czemu są w stanie funkcjonować niezależnie (il. 7). Analogicznie jak w gmachu Bauhausu w Dessau - wyodrębnione w przestrzeni funkcje budynku połączone są łącznikami, zaś w centrum całego układu zlokalizowano pomieszczenia dyrekcji i administracji.

W warstwie interpretacyjnej podobieństwo obu rozwiązań nie jest jednak oczywiste. Gropius, rozczłonkowując bryłę szkoły w Dessau, nawiązywał do postulatów Theo van Doesburga dążącego do przełamania układów osiowych i hierarchii elewacji występujących w tradycyjnej architekturze. Podejście to stało się jednym z podstawowych postulatów awangardy w opozycji do ściśle hierarchicznej architektury XIX w. Szkoła w Dessau nie ma frontu - przynajmniej cztery elewacje obiektu są niemal równoważne, a wszystkie pozostałe są w równym stopniu dostępne dla odbiorcy.

Z kolei w szkole w Podkowie Leśnej rozczłonkowanie bryły obiektu jest podyktowane przede wszystkim optycznym pomniejszaniem jego skali, aby nie zdominował rozciągającego się wokół miasta ogrodu z sąsiadującym ze szkołą kameralnym kościołem i stojącymi wśród drzew domami jednorodzinnymi. Wyraźnie reprezenta- gymnasium was clearly hidden at the back, giving it a secondary status within the body of the building [11]. The breakdown into functional blocks can be interpreted as an emanation of the ideas of modernists, in line with the principle that "form follows function". Nevertheless, in this case, this division results rather from the fact that the three consecutive stages of the school project were created at different times, which corresponded to the subsequent stages of the investments which were implemented one after another due to the financing of the school construction from funds acquired gradually.

Although both buildings have a functional layout based on a similar principle, the architecture of the school in Podkowa Leśna differs from the purist modernism clearly referring to the function. The façades of the building feature decorative elements devoid of any utilitarian justification, such as corner window embrasures clearly protruding in front of the building face. Contemporary references to traditional architecture in the form of slanted fragments of the attic, which refer to the sloping roofs of the neighboring single-family houses and the building of the nearby church, are also legible.

\section{Structure and detail - WRiTV headquarters in Katowice}

The project in which the designers from the Grupa 5 Architekci studio referred to the heritage of Mies van der Rohe is the headquarters of the Faculty of Radio and Television of the University of Silesia in Katowice (WRiTV). The construction of the facility was completed in 2017. The project is the result of close cooperation of three studios - Warsaw studio (Grupa 5 Architekci), Catalan studio (BAAS Arquitectura) and Katowice studio (MAŁECCY Biuro Projektowe). The building completes the gap in the frontage of Św. Pawła street and adjoins a low brick building of the Silesian tenement house (familok), which 

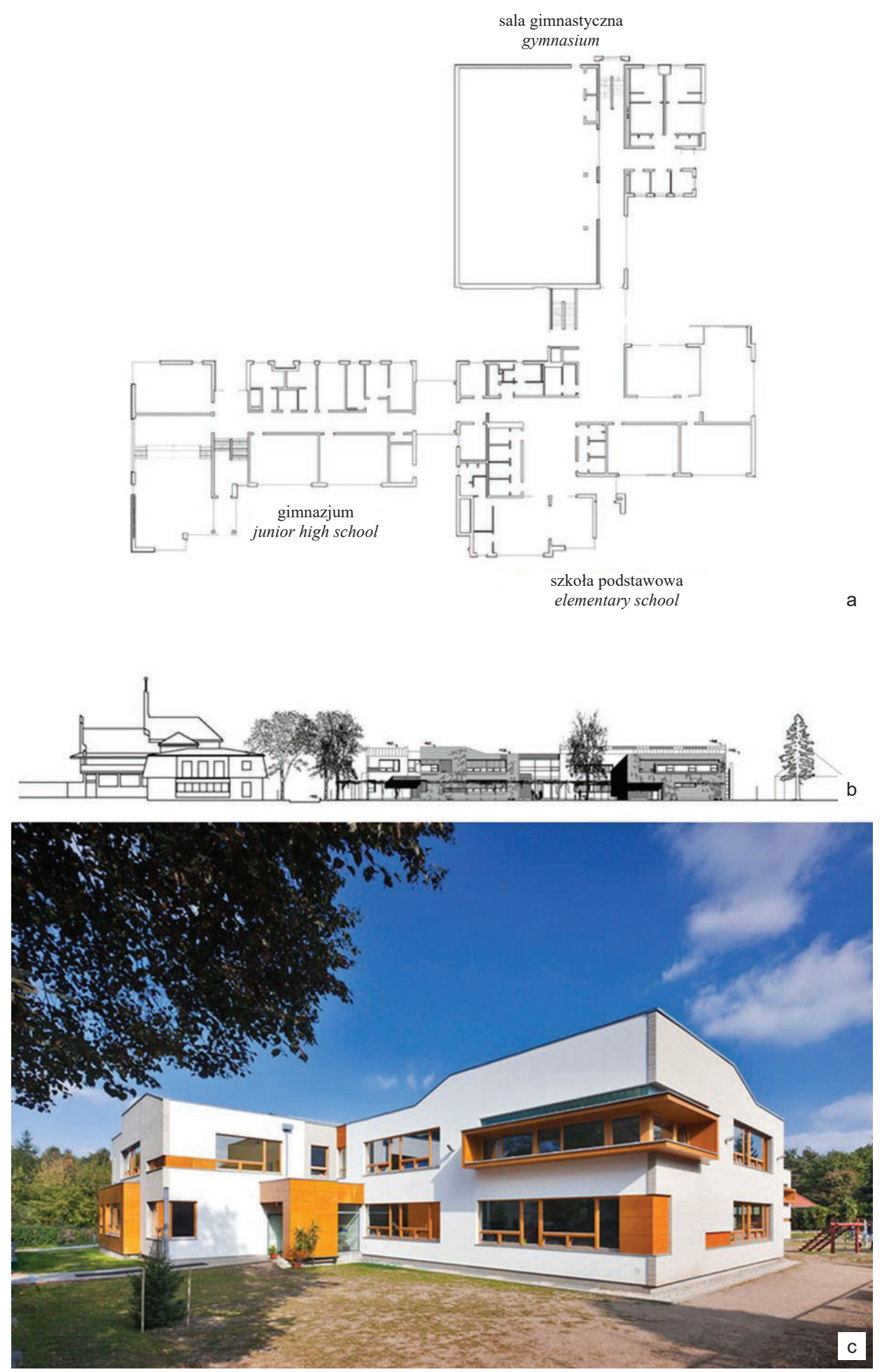

Il. 7. Szkoła Podstawowa im. Św. Teresy od Dzieciątka Jezus w Podkowie Leśnej autorstwa Grupa 5 Architekci: a) rzut parteru, b) elewacja poludniowa, c) narożnik południowo-zachodni $\mathrm{z}$ jednym $\mathrm{z}$ wejść do budynku (fot. M. Czechowicz)

Fig. 7. The St. Therese of the Child Jesus Primary School in Podkowa Leśna designed by Grupa 5 Architekci: a) ground floor plan, b) southern façade, c) south-west corner with one of the entrances into the building (photo by M. Czechowicz)

cyjne i bardziej doinwestowane materiałowo elewacje z wejściami do wszystkich trzech sekcji budynku szkoły zlokalizowano od strony ulic. Jednocześnie największą kubaturę sali gimnastycznej wyraźnie ukryto na tyłach, nadając jej w bryle budynku drugorzędny status [11]. Rozbicie na bloki funkcjonalne może być interpretowane jako emanacja idei modernistów, zgodnie z regułą, iż ,forma wynika z funkcji”. Niemniej w tym wypadku podział ten wynika raczej z faktu, iż trzy kolejne etapy projektu szkoły powstały w różnym czasie, co odpowiadało kolejnym etapom inwestycji, które realizowane były po sobie after restoration has become an integral part of the building housing the faculty library. The minimalist building of the faculty, seen from the street, forms the background architecture - its openwork façade, made of traditionally fired ceramic blocks, blends into the vicinity of old tenement houses [12, pp. 40-60]. The facility is located in one of the oldest parts of the city. Its structure was integrated with the existing urban tissue, which required supplementation [13].

The WRiTV headquarters, whose constructional structure is partly a regular grid of poles, is in fact a glass 
ze względu na finansowanie budowy szkoły ze stopniowo pozyskiwanych środków.

Mimo że oba budynki mają rozplanowanie funkcjonalne oparte na podobnej zasadzie, architektura szkoły w Podkowie Leśnej odbiega od jednoznacznie nawiązującego do funkcji purystycznego modernizmu. Na elewacjach budynku pojawiają się, pozbawione utylitarnego uzasadnienia, elementy dekoracyjne - takie jak wyraźnie wysunięte przed lico budynku narożne glify okienne. Czytelne są też współczesne odniesienia do architektury tradycyjnej w postaci skośnych fragmentów attyki, które nawiązują do spadzistych dachów sąsiednich domów jednorodzinnych i budynku pobliskiego kościoła.

\section{Struktura i detal - siedziba WRiTV w Katowicach}

Realizacją, w której projektanci z pracowni Grupa 5 Architekci nawiązali do dziedzictwa Miesa van der Rohe jest siedziba Wydziału Radia i Telewizji Uniwersytetu Śląskiego w Katowicach (WRiTV). Budowę obiektu zakończono w 2017 r. Projekt jest rezultatem ścisłej współpracy trzech pracowni - warszawskiej (Grupa 5 Architekci), katalońskiej (BAAS Arquitectura) i katowickiej (MAŁECCY Biuro Projektowe). Gmach uzupełnia lukę w pierzei ul. Św. Pawła i przylega do niskiego ceglanego budynku śląskiego familoka, który po odrestaurowaniu stał się integralną częścią obiektu mieszczącą wydziałową bibliotekę. Minimalistyczny gmach wydziału widziany od strony ulicy stanowi architekturę tła - jego ażurowa fasada, wykonana z wypalanych metodą tradycyjną pustaków ceramicznych, wtapia się w sąsiedztwo starych kamienic [12, s. 40-60]. Obiekt zlokalizowany jest w jednej z najstarszych części miasta. Jego struktura została zintegrowana $\mathrm{z}$ istniejącą tkanką urbanistyczną, która wymagała uzupełnień [13].

Siedziba WRiTV, której strukturę konstrukcyjną stanowi po części regularna siatka słupów, to w istocie szklany budynek, jedynie opakowany ażurową ceramiczną osłoną nawiązującą do klimatu lokalnego budownictwa (il. 8). Zewnętrzne przegrody budynku w obrębie parteru zaprojektowano jako całkowicie przezroczyste, dzięki czemu ulica, poprzez przeszklony hall, pozostaje w przestrzennej relacji ze zlokalizowanym w głębi działki dziedzińcem, zaś dziedziniec niemal ,wychodzi” na ulicę.

Śląski obiekt można uznać za hołd złożony metodzie projektowania zapoczątkowanej przez Miesa van der Rohe. Architekci z Polski i Katalonii potwierdzili te fascynacje, podkreślając w budynku katowickiego wydziału jego strukturę konstrukcyjną w postaci stalowych i żelbetowych słupów o krzyżowym przekroju, bezpośrednio nawiązujących do detali stosowanych przez van der Rohe w wielu jego obiektach - od zaprojektowanego w 1929 r. niemieckiego pawilonu na międzynarodowej wystawie w Barcelonie, poprzez willę Tugendhatów w Brnie z roku 1930, do ukończonej w 1968 r. berlińskiej Nowej Galerii Narodowej.

Katowicki gmach WRiTV, w przeciwieństwie do wolnostojących i zazwyczaj stylistycznie niepowiązanych z sąsiedztwem budynków van der Rohe, jest gmachem
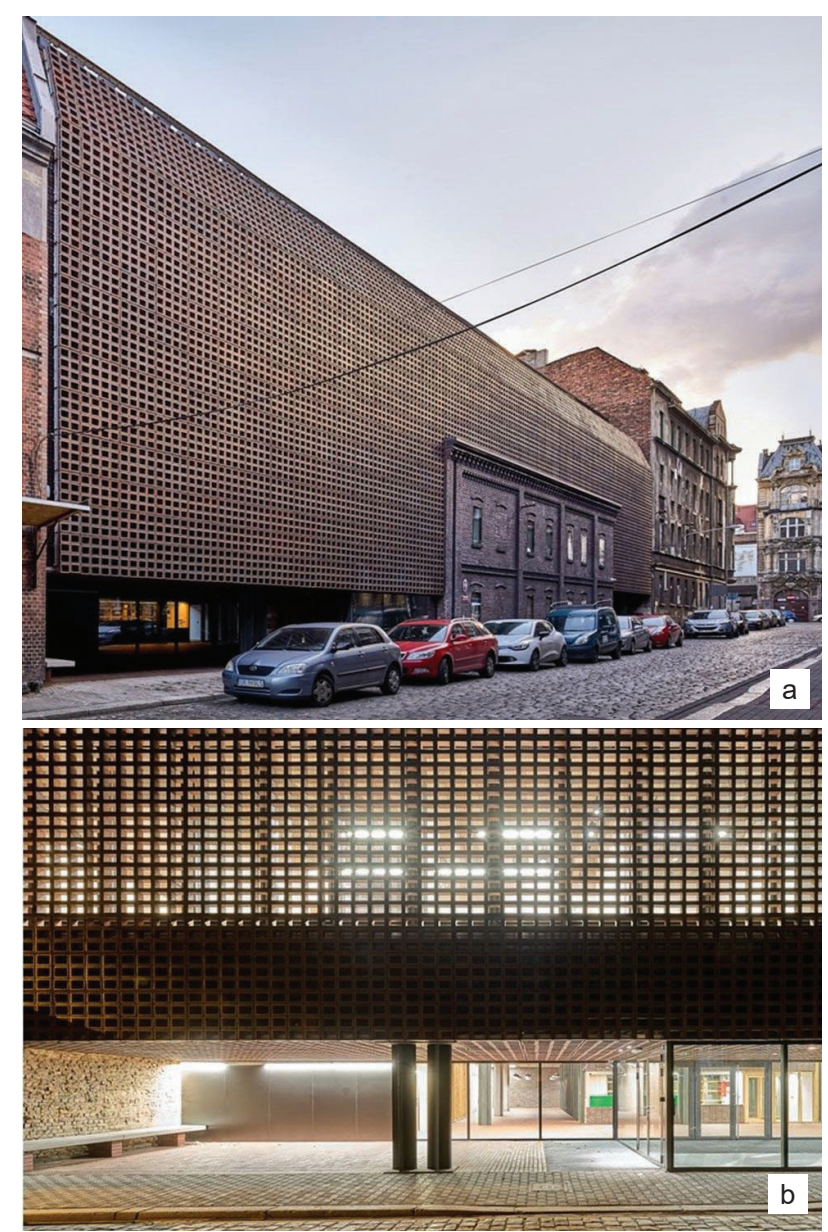

Il. 8. Siedziba Wydziału Radia i Telewizji Uniwersytetu Śląskiego w Katowicach (projekt: BAAS Arquitectura/ Grupa 5 Architekci / MAŁECCY Biuro Projektowe, 2011-2014): a) elewacja północna przyległa do ulicy Św. Pawła, b) fragment elewacji północnej z widocznym detalem przykrywającej budynek ażurowej osłony ceramicznej i słupami o krzyżowym przekroju (fot. J. Certowicz)

Fig. 8. The headquarters of the Faculty of Radio and Television of the University of Silesia in Katowice (design: BAAS Arquitectura / Grupa 5 Architekci / MAŁECCY Biuro Projektowe, 2011-2014): a) the northern façade adjoining Św. Pawła Street, b) a fragment of the northern façade with a visible detail of the openwork ceramic cover covering the building and cross-section columns (photo by J. Certowicz)

building, only wrapped in an openwork ceramic cover referring to the atmosphere of the local building industry (Fig. 8). The external partitions of the building within the ground floor have been designed as completely transparent, thanks to which the street, through the glazed hall, remains in a spatial relationship with the courtyard located in the back of the plot, and the courtyard almost "looks out onto" the street.

The Silesian facility can be considered to be a tribute to the design method initiated by Mies van der Rohe. Architects from Poland and Catalonia confirmed these fascinations, emphasizing in the building of the Katowice faculty its constructional structure in the form of steel and reinforced concrete columns with a cross-section, directly 


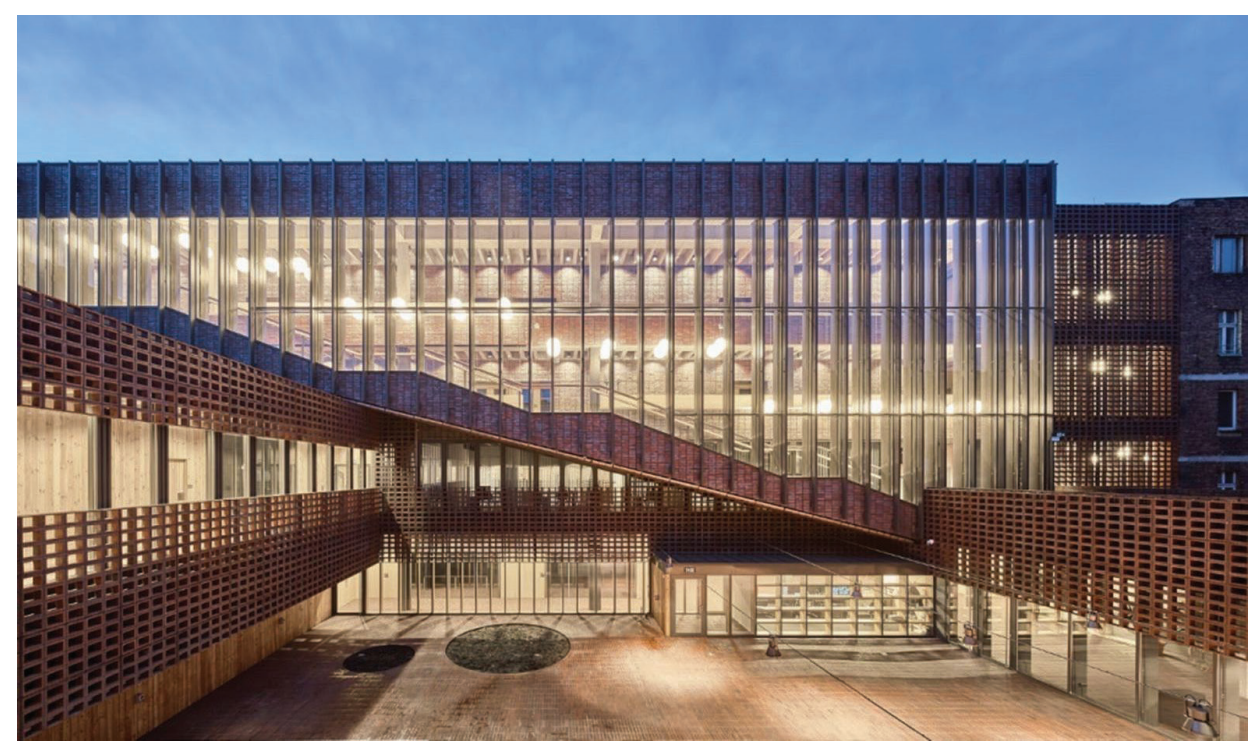

Il. 9. Dziedziniec siedziby WRiTV w Katowicach (fot. J. Certowicz)

Fig. 9. The courtyard of the WRiTV headquarters in Katowice

(photo by J. Certowicz) ściśle związanym z zastanym kontekstem. Jeden z jego współautorów, Katalończyk Jordi Badia, tak podsumował założenia ideowe tej realizacji: Strategia projektowa nie polega na tym, by zbudować ikone, ale by zbudować i uzupetnić fragment miasta. Trzeba przyjrzé się temu, co istnieje, odkryć, dlaczego jest wyjątkowe, a potem nadać szczególna atmosferę $i$ osobowość [12, s. 44]. O wyraźnym wpisaniu budynku w zastany kontekst decyduje nie tylko tradycyjny śląski materiał użyty na elewacjach, ale i rzut obiektu. Pomieszczenia szkoły okalają wewnętrzny dziedziniec (il. 9), tworząc układ nawiązujący bezpośrednio, również skalą, do tradycyjnej oficynowej zabudowy, dzięki czemu budynek niemal niezauważalnie wtapia się w tkankę urbanistyczną starej części Katowic.

\section{Wnioski}

Analiza przywołanych powyżej realizacji architektonicznych wskazuje, iż nawet bezpośredniemu inspirowaniu się motywami zaczerpniętymi z projektów twórców Bauhausu nie musi dziś towarzyszyć dogmatyzm charakterystyczny dla epoki awangardy. Modernistyczne rozwiązania mogą służyć odmiennym niż niegdyś celom, które nie stawiają na pierwszym planie arbitralnej nowoczesności. Wszystkie przedstawione tu projekty autorstwa współczesnej warszawskiej pracowni zdeterminowane są relacją z sąsiedztwem, zaś poszczególne rozwiązania projektowe, nawet jeśli tkwią korzeniami we wczesnym modernizmie, odgrywają wobec kontekstu rolę służebną.

Grupa 5 Architekci to jedna z wielu polskich pracowni działających w realiach społeczeństwa ponowoczesnego i rozwiniętej gospodarki rynkowej. Jej założyciele, podobnie jak wielu rodzimych projektantów w średnim wieku, nie widzą swojej przyszłości w projektowaniu ikonicznych prototypów [6, s. 84]. Krytycy architektury mają trudność ze zdefiniowaniem twórczości tego pokolenia architektów. W 2004 r. frustrację wobec braku ambicji przedstawicieli swojej generacji do tworzenia jednoznacznego języka architektury wyraził na łamach referring to the details used by van der Rohe in many of its buildings - from the German pavilion designed in 1929 for the international exhibition in Barcelona, through the Tugendhat villa in Brno from 1930, to the New National Gallery in Berlin, completed in 1968.

The Katowice building of WRiTV, in contrast to the detached buildings, usually stylistically unrelated to the neighborhood of van der Rohe buildings, is an edifice closely related to the existing context. One of its co-authors, the Catalan Jordi Badia, summed up the ideological assumptions of this implementation in the following words: The design strategy is not to build an icon, but to build and complete a fragment of the city. You have to look at what already exists, discover why it is unique, and then grant it a special atmosphere and personality [12, p. 44]. The fact that the building clearly blends in with the existing context is determined not only by the traditional Silesian material used on the façades, but also by the building projection. The school's rooms surround the inner courtyard (Fig. 9), creating a layout that directly refers, also by its scale, to the traditional outbuilding, thanks to which the building almost imperceptibly merges into the urban tissue of the old part of Katowice.

\section{Conclusions}

The analysis of the above-mentioned architectural projects shows that even when directly inspired by the motifs taken from the designs of the Bauhaus artists, it does not have to be accompanied by the dogmatism typical for the avant-garde era. Modernist solutions may serve purposes different than before, which do not put arbitrary modernity in the foreground. All the designs presented here, developed by a contemporary Warsaw studio are determined by the relationship with the neighborhood, and the individual design solutions, even if they are rooted in early modernism, play an auxiliary role in relation to the context.

Grupa 5 Architekci is one of many Polish studios operating in the realities of postmodern society and developed market economy. Its founders, like many middle-aged 
„Architektury Murator” architekt Grzegorz Stiasny: [...] sa przeważnie zapalonymi neomodernistami, pozbawionymi jednak ideowego szkieletu, jaki może dać architektoniczna teoria. Dlatego ich dzieła to przeważnie modernizm dla mięczaków [14, s. 99]. Opinia ta zakłada, iż dzisiejszy projektant, podobnie jak w czasach wczesnego modernizmu, powinien odegrać rolę spójnego ideowo walczącego twórcy. Czytelna jest w niej pogarda wobec postawy kompromisowej uwzględniającej wciąż zmieniający się kontekst ekonomiczny i społeczny oraz wobec traktowania konkretnych rozwiązań z czasów minionych wyłącznie jako logicznych sprawdzonych patentów wzbogacających warsztat architekta.

Tymczasem brak krępującego „ideowego szkieletu” to w pełni uświadomiona cecha projektantów z Grupy 5 Architekci. Istotniejszy jest dla nich architektoniczny pluralizm i różne, często intuicyjne, mierzenie się z zagadnieniami każdego budynku, chociażby ze względu na jego różne sąsiedztwo i kontekst kulturowy [6, s. 87-89].

Warto przy tym pamiętać, iż Walter Gropius pod koniec życia dystansował się wobec obecnej w szkole Bauhausu funkcjonalistycznej retoryki. We wstępie do wydanej w 1956 r. książki Petnia architektury napisał: Nie istnieje coś takiego jak ,styl międzynarodowy”, chyba że mamy na myśli osiagnięcia techniczne naszych czasów o uniwersalnym zasięgu, wspóltworzace zaplecze intelektualne każdego cywilizowanego narodu. [...] Stalowy lub żelbetowy szkielet, okna pasmowe, płyty na wspornikach, czy całe skrzydła budynków na stupach sa wyłacznie bezosobowymi, nowoczesnymi środkami - rodzajem „,surowego” materiału - które umożliwiaja powstawanie zróżnicowanych regionalnie zjawisk architektonicznych [15, s. 15, 16]. native designers, do not see their future in designing iconic prototypes [6, p. 84]. Architecture critics find it difficult to define the works of this generation of architects. In 2004, architect Grzegorz Stiasny expressed his frustration in the magazine "Architektury Murator" at the lack of ambition of his generation to create an unambiguous language of architecture: [...] they are mostly eager neo-modernists, but lacking the ideological framework that architectural theory can provide. Therefore their works mostly represent modernism for the softies [14, p. 99]. This opinion assumes that today's designer, just like in the times of early modernism, should play the role of an ideologically coherent and struggling creator. It clearly shows contempt for a compromise attitude that takes into account the ever-changing economic and social context, and for treating specific solutions from the past only as logical proven patents enriching the architect's workshop.

Meanwhile, the lack of an embarrassing "ideological framework" is a fully conscious feature of the designers from Grupa 5 Architekci. For them, architectural pluralism and various, often intuitive, solving of the issues of each building is more important, if only because of its different neighborhood and cultural context [6, pp. 87-89].

It is worth remembering that Walter Gropius at the end of his life distanced himself from the functionalist rhetoric present in the Bauhaus school. In the introduction to the book Scope of Total Architecture, published in 1956, he wrote: There is no such thing as an "International Style", unless you want to speak of certain universal technical achievements in our period which belong to the intellectual background of every civilized nation [...] Steel or concrete skeletons, ribbon windows, slabs cantilevered or wings hovering on stilts are but impersonal contemporary means - with which regionally different architectural manifestations can be created ${ }^{4}[15$, pp. 15,16$]$.

Translated by Jadwiga Andrejczuk-Panasiuk

\footnotetext{
4 Gropius W., Scope of Total Architecture, Collier Books, New York-Ontario 1970, p. 14.
}

\section{Bibliografia/References}

[1] Banham R., Rewolucja $w$ architekturze, Wydawnictwa Artystyczne i Filmowe, Warszawa 1979.

[2] Jencks Ch., Ruch nowoczesny w architekturze, Wydawnictwa Artystyczne i Filmowe, Warszawa 1987.

[3] Naylor G., Bauhaus, Wydawnictwa Artystyczne i Filmowe, Warszawa 1988.

[4] Blake P., Mies van der Rohe - architektura i struktura, Wydawnictwa Artystyczne i Filmowe, Warszawa 1991.

[5] Pevsner N., Pionierzy współczesności. Od Williama Morrisa do Waltera Gropiusa, Wydawnictwa Artystyczne i Filmowe, Warszawa 1978.

[6] Życie i przestrzeń: Grupa 5 Architekci, Grupa 5 Architekci, Warszawa 2018.

[7] Mycielski K., Kim wy jesteście pampersi?, „Architektura Murator” 1998, Nr 5(44), 70-71.

[8] Apartament „Morskie Oko” - willa na skarpie, „Forum Nowoczesnego Budownictwa" 2018, Nr 3(5), 4-10.
[9] Droste M., Bauhaus 1919-1933, Taschen, Berlin 2006.

[10] Piękna 49 w Warszawie, ,Architektura Murator” 2018, Nr 2(281), $34-46$.

[11] Gaete J., Elementary School near Warsaw / Grupa 5 Architekci, https://www.archdaily.com/276617/elementary-school-nearwarsaw-grupa-5-architekci [accessed: 13.10.2012].

[12] Wydziat Radia i Telewizji, „Architektura Murator” 2018, Nr 03(282), 40-60.

[13] Fakultät für Radio und Fernsehen in Kattowitz, „Detail” 2019, No. 3, 74-83.

[14] Stiasny G., Od A do Z - alfabet architektoniczny, „Architektura Murator" 2004, Nr 10(120), 86-110.

[15] Gropius W., Petnia architektury, Karakter, Kraków 2014 


\section{Streszczenie}

Celem artykułu jest przeanalizowanie rozwiązań projektowych i idei obecnych w architekturze Bauhausu, które można dziś zaobserwować w polskiej praktyce projektowej. Analizę zawężono do wybranych dzieł Waltera Gropiusa i Miesa van der Rohe, zestawiając je z projektami warszawskiej pracowni Grupa 5 Architekci, reprezentatywnej dla pokolenia architektów średniego pokolenia, dominującego dziś na polskim rynku architektonicznym. Analiza prowadzi do wniosku, iż nawet bezpośredniemu inspirowaniu się motywami zaczerpniętymi z projektów twórców Bauhausu nie towarzyszy dziś ideologiczna arbitralność charakterystyczna dla epoki awangardy.

Slowa kluczowe: Bauhaus, Walter Gropius, Mies van der Rohe, Grupa 5, praktyka projektowa

\section{Abstract}

The aim of the article is to analyse design solutions and ideas present in Bauhaus architecture that can be observed today in Polish design practice. The analysis has been narrowed down to selected works of Walter Gropius and Mies van der Rohe by juxtaposing them with the designs of the Warsaw studio Grupa 5 Architekci, a representative of the middle generation of architects who dominate the Polish architectural market today. The analysis leads to the conclusion that even directly inspired by motifs taken from the projects of the creators of Bauhaus, today is not accompanied by the ideological arbitrariness characteristic of the avant-garde era.

Key words: Bauhaus, Walter Gropius, Mies van der Rohe, Grupa 5, design practice 